scientists when he meets Russian President Boris Yeltsin this week. Although the details of the plan are sketchy, it is expected to provide for Western-financed 'clearinghouses', in which researchers in Russia's crumbling defence industry could be matched with Western companies, research groups and government agencies that could use their talents. This approach is meant to encourage scientists to remain in Russia, and not share their weapons knowledge with developing nations.

But this proposal would apply to only a few thousand of the estimated one million scientists in the Russian research establishment. And some US policy experts are concerned that it might send the wrong message to that community. "Those researchers who made a conscious and moral choice not to work in the Soviet defence industry should not be ignored," says Harley Balzer, director of the Russian studies programme at Georgetown University in Washington, DC.

Other projects intended to help the former Soviet Union appear to ignore Russian science altogether. A bill in Congress that would give the US Agency for International Development (AID) \$645 million to provide the former Soviet Union with humanitarian and "technical" aid would not include research funds, according to Hiram Larew, a member of the AID strategic planning office. "There has been virtually no mention of research activities in the current [AID] plan" to give aid to the region, he told the AAAS panel.

One of the few concrete plans for Russian science is not coincidentally one of the smallest. The AAAS international office has decided to focus on helping Russian institutions to resume their subscriptions to foreign scientific journals. In January the Russian Academy of Sciences cut the funds for all its institutes' subscriptions, which virtually isolates most Russian researchers from developments in the West. Although several journals (including this one), have agreed to continue Russian subscriptions at cost, money for even that reduced expense is not available in Russia, and has so far been slow in coming from the West. AAAS plans to use a $\$ 2,000$ grant from the Chicago-based MacArthur Foundation to survey scientific societies and leading journals to discover how many subscriptions have been affected by the Russian measure. Association officials hope to raise several million dollars from private foundations to refill Russian bookshelves.

Despite the limitations of current proposals, there is no shortage of goodwill towards Russian science. Individual efforts from US researchers have gone as far as food shipments and personal cheques. But short of direct contact with people in Russia, there are few mechanisms to ensure that private donations will get into the right hands.

Christopher Anderson

\title{
Tragedy revealed in Zurich
}

\section{London}

A TRAGIC case of scientific misconduct, revealed last week by the University of Zurich, underlines the importance of ensuring that key data are replicated reliably before publication and that several members of a research team are able to carry out difficult experimental procedures.

The case centres around a claim, first published in the EMBO Journal $(9,385$; 1990), that researchers at the University of Zurich's Institute of Molecular Biology had produced functioning measles viruses by microinjecting cultured human cells with cloned complementary DNA (cDNA) produced from the RNA genome of the virus. The data underlying the claim, provided by Isidro Ballart, a South American $\mathrm{PhD}$ student working at the institute, were later found to be fraudulent. On $20 \mathrm{March}$ 1991, shortly before evidence of the fraud began to emerge, the student was found dead in his laboratory.

Martin Billeter, the leader of the research group, last autumn retracted the EMBO Journal paper as well as a second publication, based on the fraudulent data, that appeared in the Journal of Virology $(65,3161 ; 1991)$. But the university was able to reveal the case only last Friday (7 February), having been sworn to secrecy until a Zurich district attorney had completed a full inquiry into Ballart's death. His death has been ruled a suicide.

The EMBO Journal paper caused a stir among virologists. The study of negativestrand RNA viruses (in which the single strand of RNA must produce a complementary copy of itself inside the host cell before viral proteins can be transcribed) has been hindered by the lack of an experimental system for genetic manipulation. Using the model system Ballart developed, Billeter's group aimed to produce genetically engineered measles viruses by manipulating the cDNA injected into the cultured cells. Their aim was to study the function of individual measles genes, in particular the mutant genes associated with a fatal disease of the central nervous system, subacute sclerosing panencephalitis, which occurs in about one in 100,000 cases of measles.

The model system might also have allowed the production of new genetically engineered vaccines. "It would have been the most important breakthrough in our area of virology for the past 10 years," says Dan Kolakofsky, from the University of Geneva.

But the euphoria in Billeter's group came to an abrupt end with the discovery of Ballart's body. At first, it was thought he had died from natural causes. A routine examination by the university's Institute of Forensic Medicine found no evidence of poisoning. But a subsequent detailed autopsy revealed that Ballart had taken his own life by swallowing a quantity of "a common inorganic chemical", says Charles Weissmann, director of the Institute of Molecular Biology.

Meanwhile, other $\mathrm{PhD}$ students in Billeter's group were discovering that viruses purportedly produced in cell culture from cloned cDNA were no different from the standard Edmonston measles virus strain used in the laboratory. At first, nobody suspected that the dead student was guilty of fraud, instead assuming that the cell cultures must have been inadvertently contaminated with the laboratory strain. "He was very popular," says Billeter, and "always willing to help his colleagues."

But when other members of the group consistently failed to replicate Ballart's results, Billeter and his colleagues began to work systematically through the preparations left behind. The evidence pointed to one conclusion: the student had not been able to produce viable viruses by microinjecting cultured cells with cloned cDNA; instead, he had simply infected the cell cultures with the standard lab-strain virus. His genetic analyses, showing marker genes present in the cDNA, came not from viral cell culture, but from the original cDNA samples. Weissmann says that the fraud went undiscovered until other members of Billeter's group began conducting their own genetic analyses, using viruses supplied by Ballart.

In July 1991, Billeter wrote to his colleagues in the field, explaining the circumstances of the fraud; published retractions soon followed. In August, Weissmann and Billeter also pressed the university's rector to appoint an external commission to sift through the data. But the university took no further action after Clive Kuenzle, a biochemist and one of the university's pro-rectors, concluded that the evidence indicated clearly that the dead student had acted alone.

Virologists agree that Billeter was diligent in informing his colleagues in the field about the fraud. Still, the effect on Billiter's group has been debilitating: the researchers involved went through "a year of catharsis", says Kolakofsky.

The tragedy also points out the problems that can arise when experiments hinge on the performance of a difficult technique by a single relatively inexperienced researcher. For more than a year, Ballart alone was responsible for microinjecting cDNA into cultured cells and for performing the genetic analyses supposed to show that the viruses produced in the culture were derived from the cDNA. "I'm sorry that I didn't insist at the time that other members of my group also learn to do the mîcroinjection," says Billeter.

Peter Aldhous 